\title{
Modulations of genes related to gut integrity, apoptosis, and immunity underlie the beneficial effects of Bacillus amyloliquefaciens CECT 5940 in broilers fed diets with different protein levels in a necrotic enteritis challenge model
}

Kosar Gharib-Naseri ${ }^{1}$, Juliano Cesar de Paula Dorigam² ${ }^{2}$ Kiran Doranalli², Sarbast Kheravii ${ }^{1}$, Robert A. Swick ${ }^{1}$, Mingan $\mathrm{Choct}^{3}$ and Shu-Biao $\mathrm{Wu}^{{ }^{*}}$ (i)

\begin{abstract}
Background: The ban of in-feed antimicrobial additives has negatively affected the poultry industry by causing necrotic enteritis (NE) to emerge in the flocks. Alternatives such as Bacillus probiotics have shown to be effective on eliminating the negative effects of this disease. Two experiments were conducted to investigate the effect of Bacillus amyloliquefaciens CECT 5940 (BA) in broiler chickens under NE challenge and/or fed diets with different protein levels.

Methods: In both experiments, 480 day-old mix-sexed Ross-308 broilers were arranged in a $2 \times 2$ factorial arrangement of treatments. In experiment 1, the factors were NE challenge (yes or no) and probiotic (yes or no). In experiment 2, the factors were dietary crude protein levels (standard or reduced) and probiotic (yes or no) and were used under NE challenge condition. Oral administration of Eimeria oocysts (day 9) followed by inoculation with Clostridium perfringens (day 14 and 15) was used to induce NE challenge. On day 16, two birds from each treatment were gavaged with fluorescein isothiocyanate-dextran (FITC-d) and blood samples were collected for gut integrity evaluation, and jejunal samples were collected for gene expression assay.

(Continued on next page)
\end{abstract}

* Correspondence: shubiao.wu@une.edu.au

'School of Environmental and Rural Science, University of New England, Armidale, NSW 2351, Australia

Full list of author information is available at the end of the article

C C The Author(s). 2020 Open Access This article is licensed under a Creative Commons Attribution 4.0 International License, which permits use, sharing, adaptation, distribution and reproduction in any medium or format, as long as you give appropriate credit to the original author(s) and the source, provide a link to the Creative Commons licence, and indicate if changes were made. The images or other third party material in this article are included in the article's Creative Commons licence, unless indicated otherwise in a credit line to the material. If material is not included in the article's Creative Commons licence and your intended use is not permitted by statutory regulation or exceeds the permitted use, you will need to obtain permission directly from the copyright holder. To view a copy of this licence, visit http://creativecommons.org/licenses/by/4.0/. The Creative Commons Public Domain Dedication waiver (http://creativecommons.org/publicdomain/zero/1.0/) applies to the data made available in this article, unless otherwise stated in a credit line to the data. 
(Continued from previous page)

Results: In experiment 1, BA supplementation decreased caspase-3 (CASP3) $(P<0.001)$ and caspase-8 (CASP8) (P < $0.05)$ and increased occludin $(O C L D)(P<0.05)$ expression regardless of the challenge. Additionally, BA supplementation downregulated interfron- $\gamma$ (IFN- $\gamma)$ expression $(P<0.01)$ and upregulated immunoglobulin-G (IgG) $(P<0.01)$ and immunoglobulin-M (IgM) $(P<0.05)$ only in challenged birds. In experiment 2 , the expression of genes encoding mucin-2 (MUC2) $(P<0.001)$, tight junction protein-1 (TJP1) $(P<0.05)$ and $O C L D(P<0.05)$ were upregulated by the addition of BA in the diet, regardless of the crude protein level. Further, BA supplementation downregulated INF- $\gamma(P<0.01)$ and upregulated immunoglobulin-A $(\lg A)(P<0.05)$, IgM $(P<0.05)$ and $\lg G(P<0.01)$ regardless of the crude protein level.

Conclusion: These findings suggest that supplementation of BA in broiler diets can improve gut health by modulation of genes related to the mucosal barrier, tight junction, and immunity in broilers challenged by unfavourable conditions such as NE challenge.

Keywords: Bacillus amyloliquefaciens, Broiler, Clostridium perfringens, Gene expression, Necrotic enteritis, Probiotic

\section{Background}

The primary cause of necrotic enteritis (NE) in chickens is the bacterium Clostridium perfringens. The acute clinical form of this disease leads to significant flock mortality, whereas the subclinical form can decrease weight gain with a subsequent loss of productivity. The NE infection has become a significant economical concern for poultry farmers, especially in the subclinical form [1], leading to a US\$6 billion annual loss to the global poultry industry [2]. In-feed antimicrobials show effective NE control, however, the ban of these additives has negatively affected the poultry industry by causing NE to emerge in the flocks [3]. Many alternatives to in-feed antibiotics have been explored to improve microbial balance and maintain growth performance of broilers [4]. Bacillus species are used as probiotics in animal industry and have shown many positive effects on maintained broiler health [5]. Because of the inherent capacity of Bacillus bacterium to withstand harsh conditions in feed processing such as pelleting and conditioning at high temperature and under harsh acidic conditions in the gut, they are a suitable option to be used in broiler diets. Among the Bacillus species, B. amyloliquefaciens (BA) has shown substantial antimicrobial activities $[6,7]$ and produces several extracellular enzymes such as $\alpha$ amylase, cellulase, and proteases that enhance digestibility and absorption of nutrients [8]. These strains can also produce different bacteriocins, such as barnase and binase which can be effective in controlling $C$. perfringens $[9,10]$. Furthermore, the quorum quenching activity of BA can disturb the quorum sensing signaling molecules of some pathogenic bacteria, which is essential for the communication and growth of these microorganisms, and thereby inhibit the growth of the harmful groups $[11,12]$.

The importance of the intestinal tract and its critical role in nutrient absorption and immune responses is evident [13]. The mucosal barrier mechanism in the small intestine serves as the body's first line of defence and can maintain an essential barrier to microbial invasion and protect the intestinal epithelial cells [14]. Mucin proteins such as, mucin-2 (MUC2) and mucin-5 ac (MUC5ac, maintain a suitable thickness of the mucous layer, as this layer is often sloughed off by intestinal movements or microbial-derived factors [15]. Immunoglobulin proteins such as immunoglobulin-A (IgA), immunoglobulin-M (IgM) and immunoglobulin-G (IgG/ IgY) are present in the enterocyte brush border and are delivered to the mucus layer to perform immune exclusion and clearance of antigens [16]. Furthermore, intestinal absorbing epithelial cells are strongly connected by tight junction proteins such as claudin-1 (CLDN1), occludin (OCLD) and tight junction protein-1 (TJP1). The function of these proteins is necessary for controlling permeability on the paracellular pathways. Furthermore, while apoptosis (cell death) usually happens during development and aging, it can also occur in defense mechanisms such as DNA damage caused by UV light, ionizing radiation, disease or toxic agents [17]. Activation of caspase proteases correlates with the onset of apoptosis and cell death [18]. Sucrase-isomaltase (SI), ATPase $\mathrm{Na}^{+} / \mathrm{K}^{+}$transporting subunit alpha-1 (ATP1A1) and glucose transporter-2 (GLUT2) proteins in the intestinal epithelium are closely associated with intestinal nutrient digestion and absorption capacity [19-21]. Altogether, the level of expression of these genes in the different groups of this study can illustrate a better understanding of BA supplementation in the birds.

The high cost of protein sources and environmental concerns related to high nitrogen excretion are problems faced by the poultry industry, and thus efforts have been made to decrease the dietary protein level and consequently nitrogen $(\mathrm{N})$ excretion from broiler production [22]. Furthermore, excessive dietary protein can predispose broiler chickens to NE [23]. On the other hand, reports have shown that supplementation of probiotics in 
reduced crude protein (RCP) diets can improve bird performance $[24,25]$ and litter quality and reduced incidence of footpad dermatitis [26, 27]. In this context, the combination of RCP and supplementation of probiotic could potentially contribute to the reduction in NE incidence as well as improve the bird's welfare.

Previously, performance observations of this study have shown that the supplementation of BA can improve body weight gain (BWG), feed conversion ratio (FCR) and microbial population in broilers [28]. Therefore, it was hypothesized that Bacillus amyloliquefaciens CECT 5940 as a probiotic supplement could improve gut environment so as to help reduce adverse effects of NE in chickens and positively affect growth and nutrient uptake in birds fed RCP diets. The current study used two experiments to evaluate the effect of this probiotic on NE challenge and different crude protein levels to test the above hypothesis.

\section{Methods}

All procedures of this study were reviewed and approved by the Animal Ethics Committee of the University of New England (17/127). All procedures involving the birds, including health, care, and use of laboratory animals, were fulfilled within the Code of Practice for the Use of Animals for Scientific Purposes issued by the Australian Code for the Care and Use of Animals for Scientific Purposes (NHMRC, 2013).

\section{Experimental design and diets}

Two experiments were conducted to evaluate the effect of BA supplementation under a necrotic enteritis challenge and/or on different levels of crude protein in diets. All birds in both experiments were as hatched Ross-308 chickens and were obtained from Baiada hatchery in Tamworth, NSW, Australia. Upon arrival, all birds were feather-sexed to enable allocation of the same ratio between males and females in each pen. Both experiments were designed as $2 \times 2$ factorial arrangement with 480 birds using 32 pens. Each experiment consisted of four treatments, 8 replicates, and 15 birds per pen. In experiment 1 , the factors were NE challenge (yes or no) and BA probiotic supplementation (yes or no). In experiment 2 , all birds were challenged with NE, and the treatments were dietary CP level (standard or reduced) and BA probiotic supplementation (yes or no).

In both experiments, the dietary concentration of probiotic was $1 \times 10^{6} \mathrm{CFU}$ of Bacillus amyloliquefaciens CECT 5940 per $g$ of feed. All pens were within the same environmentally controlled facility, equipped with a bell feeder and cup drinkers. Broiler chickens had ad libitum access to feed and water. Ingredients and nutrient composition of the diets are shown in Table 1. The lighting, relative humidity, and temperature were maintained following Ross-308 guidelines [29]. The chickens were fed
Table 1 Composition and nutritional content of the experimental diets

\begin{tabular}{|c|c|c|c|c|}
\hline \multirow[t]{2}{*}{ Ingredients, \% } & \multicolumn{2}{|c|}{ Starter (d 0-10) } & \multicolumn{2}{|c|}{ Grower (d 11-16) } \\
\hline & $\overline{S C P^{C}}$ & $R C P^{d}$ & $\overline{\mathrm{SCP}}$ & $\mathrm{RCP}$ \\
\hline Wheat & 39.9 & 49.5 & 42.6 & 52.3 \\
\hline Soybean meal & 33.2 & 24.1 & 29.2 & 20.0 \\
\hline Sorghum & 20.0 & 20.0 & 20.0 & 20.0 \\
\hline Canola oil & 2.83 & 1.38 & 3.93 & 2.47 \\
\hline Dicalcium phosphate & 1.27 & 1.33 & 1.09 & 1.15 \\
\hline Limestone & 1.24 & 1.26 & 1.16 & 1.18 \\
\hline Salt & 0.55 & 0.55 & 0.55 & 0.56 \\
\hline DL-Methionine & 0.34 & 0.38 & 0.31 & 0.35 \\
\hline L-Lysine $\mathrm{HCl} 78 \%$ & 0.27 & 0.52 & 0.25 & 0.50 \\
\hline L-Threonine & 0.16 & 0.27 & 0.14 & 0.25 \\
\hline Vitamin premix ${ }^{a}$ & 0.08 & 0.08 & 0.08 & 0.08 \\
\hline Trace mineral premix ${ }^{b}$ & 0.10 & 0.10 & 0.10 & 0.10 \\
\hline L-Valine & - & 0.12 & - & 0.12 \\
\hline L-Isoleucine & - & 0.11 & - & 0.11 \\
\hline L-Arginine & - & 0.18 & - & 0.19 \\
\hline Choline chloride $60 \%$ & 0.03 & 0.07 & 0.03 & 0.07 \\
\hline Phytase & 0.01 & 0.01 & 0.01 & 0.01 \\
\hline Titanium dioxide & - & - & 0.50 & 0.50 \\
\hline \multicolumn{5}{|l|}{ Nutrients } \\
\hline $\mathrm{CP}, \%$ & 23.00 & 21.00 & 21.5 & 19.5 \\
\hline AMEn, kcal/kg & 3000 & 3000 & 3090 & 3090 \\
\hline Dig. Lys, \% & 1.20 & 1.20 & 1.10 & 1.10 \\
\hline Dig. Met, \% & 0.62 & 0.62 & 0.57 & 0.57 \\
\hline Dig. Arg, \% & 1.33 & 1.33 & 1.22 & 1.22 \\
\hline Dig. Ile, \% & 0.83 & 0.83 & 0.77 & 0.77 \\
\hline Dig. Val, \% & 0.90 & 0.90 & 0.84 & 0.84 \\
\hline Choline, mkg/kg & 1700 & 1700 & 1600 & 1600 \\
\hline Linoleic acid, \% & 1.68 & 1.25 & 1.99 & 1.56 \\
\hline $\mathrm{Ca}, \%$ & 0.96 & 0.96 & 0.87 & 0.87 \\
\hline Av. P, \% & 0.48 & 0.48 & 0.44 & 0.44 \\
\hline
\end{tabular}

${ }^{a}$ Supplied per kilogram of diet: vitamin $A, 8255$ IU; vitamin $D_{3}, 3000$, IU; vitamin $\mathrm{E}, 30 \mathrm{IU}$; vitamin $\mathrm{K}, 2 \mathrm{mg}$; thiamine (vitamin $\mathrm{B}_{1}$ ), $4 \mathrm{mg}$; riboflavin (vitamin $B_{2}$ ), $6 \mathrm{mg}$; niacin, $41.2 \mathrm{mg}$; folic acid, $1 \mathrm{mg}$; biotin, $0.25 \mathrm{mg}$; pyridoxine, $4 \mathrm{mg}$; choline, $1301 \mathrm{mg}$; pantothenic acid, $11 \mathrm{mg}$; vitamin $\mathrm{B}_{12}, 0.013 \mathrm{mg}$. ${ }^{b}$ Supplied per kilogram of diet: Cu (sulphate), $16 \mathrm{mg}$; Fe (sulphate), $40 \mathrm{mg}$; I (iodide), $1.25 \mathrm{mg}$; Se (selenate), $0.3 \mathrm{mg} ; \mathrm{Mn}$ (sulphate and oxide), $120 \mathrm{mg} ; \mathrm{Zn}$ (sulphate and oxide), $100 \mathrm{mg}$; cereal-based carrier, $128 \mathrm{mg}$; mineral oil, 3.75 mg., 'Standard crude protein. ${ }^{\mathrm{d}}$ Reduced crude protein

starter diets from day 0 to 10 , and grower diets were fed from day 11 until the birds were sampled at day 16 .

\section{Necrotic enteritis challenge}

To induce subclinical NE infection in birds, the University of New England NE challenge procedure as described by Rodgers et al. [30] was followed. In brief, on day 9 all challenged birds were orally inoculated with 1 
$\mathrm{mL} /$ bird field Eimeria strains (E. acervulina at 5000 oocytes/mL, E. maxima at 5000 oocytes/mL, E. brunetti at 2500 oocytes $/ \mathrm{mL}$ ); chickens in the non-challenged groups were inoculated with $1 \mathrm{~mL}$ of sterile PBS. Primary poultry isolates of $C$. perfringens (EHE-NE18) were obtained from CSIRO Livestock Industries, Geelong, Australia and was incubated overnight at $39^{\circ} \mathrm{C}$ in 100 $\mathrm{mL}$ of sterile thioglycollate broth (USP alternative; Oxoid) followed by subsequent overnight incubation of $1 \mathrm{~mL}$ of the previous culture in $100 \mathrm{~mL}$ of cooked meat medium (Oxoid), and then in $700 \mathrm{~mL}$ of thioglycollate broth (USP alternative; Oxoid) containing starch (10 g/ $\mathrm{L})$ and pancreatic digest of casein $(5 \mathrm{~g} / \mathrm{L})$ to obtain the challenge inoculum. After preparation of the inoculums, $1 \mathrm{~mL}$ of fresh inoculums containing approximately $10^{8}$ $\mathrm{CFU} / \mathrm{mL}$ C. perfringens was inoculated to the chickens on day 14 and 15 . Chickens in the unchallenged groups were gavaged with sterile thioglycolate medium as a sham treatment.

\section{Blood and intestinal tissue collection}

In both experiments, at day 16, two male birds from each pen were randomly chosen and gavaged with $1 \mathrm{~mL}$ fluorescein isothiocyanate-dextran (FITC-d) (at a dose of $4.17 \mathrm{mg} / \mathrm{kg}$ bird average body weight; molecular weight 4000, Sigma-Aldrich Co., Sydney, Australia), $2.5 \mathrm{~h}$ prior to euthanization [31]. Birds were electrically stunned, and blood was collected from the jugular vein in clot activator vacutainer tubes, immediately followed by decapitation and dissection of birds. Approximately $2 \mathrm{~cm}$ of the proximal jejunum tissue was excised, flushed with chilled sterile PBS before they were collected in $2 \mathrm{~mL}$ Eppendorf tubes containing 1.5 mL RNA later (Qiagen, Hilden, Germany) and stored at $-20^{\circ} \mathrm{C}$ until the extraction of RNA. Blood samples were kept in room temperature for approximately $3 \mathrm{~h}$ followed by $15 \mathrm{~min}$ centrifugation at $1000 \times g$ to separate red blood cells from serum. Fluorescent levels in serum samples were measured with an excitation wavelength of $485 \mathrm{~nm}$ and an emission wavelength of $528 \mathrm{~nm}$ on a Synergy HT, Multimode microplate reader SpectraMax M2e (Molecular Devices, San Jose, USA).

\section{RNA extraction and CDNA synthesis}

For each sample, total RNA from each jejunal tissue was extracted after homogenization in TRIsureTM (Bioline, Sydney, Australia) following the manufacturer's instructions. All RNA samples were purified with the RNeasy Mini Kit, (Qiagen, Hilden, Germany) following the manufacturer instructions. The quantity and purity of the samples were measured with NanoDrop ND-8000 spectrophotometer (Thermo Fisher Scientific, Waltham, USA), and the RNA Nano 6000 kit was used to measure RNA integrity on the Agilent 2100 Bioanalyzer (Agilent
Technologies, Inc., Waldron, Germany). The samples were considered as high-quality if the value of $260 / 230$ was $>2.0,260 / 280$ value between $2.0-2.2$, and the RIN number was higher than 7 . The extracted RNA of each sample was reverse transcribed with the QuantiTect Reverse Transcription Kit (Qiagen, Hilden, Germany) according to the manufacturer instructions. Rotorgene 6000 Real-Time PCR machine (Corbett, Sydney, Australia) was employed to convert RNA to cDNA. The cDNA samples were diluted 10 times with nuclease-free water and stored at $-20{ }^{\circ} \mathrm{C}$ until required.

Real-time quantitative polymerase chain reaction (RT-qPCR) Amplification and detection were carried out in duplicates using an SYBR Green kit SensiFAST SYBR No-ROX (Bioline, Sydney, Australia) with Rotorgene 6000 real-time PCR machine (Corbett Research, Sydney, Australia). The PCR reaction was performed in a volume of $10 \mu \mathrm{L}$ containing $5 \mu \mathrm{L}$ of $2 \times$ SensiFAST, $400 \mathrm{mmol} / \mathrm{L}$ of each primer and $2 \mu \mathrm{L}$ of $10 \times$ diluted cDNA template. For choosing two suitable reference genes for the analysis, the stability of eight widely used house-keeping genes (TATA-Box Binding Protein (TBP), glyceraldehyde-3-Phosphate Dehydrogenase (GADP $H)$, hydroxymethylbilane synthase $(H M B S)$, tyrosine 3monooxygenase/tryptophan 5-monooxygenase activation protein zeta (YWHAZ), cystatin C (CST3), hypoxanthine phosphoribosyltransferase 1 (HPRT1), carbonic anhydrase 2 (CA2) and Beta 2-microglobulin $(B 2 M)$ were checked in the geNorm module in qbase+ software version 3.0 (Biogazelle, Belgium) to calculate the gene expression stability measure (geNorm M) [32]. The two most stable genes with lowest $M$ value $(<0.5)$ were chosen as suitable reference gene candidates (HMBS and YWHAZ). Next, all raw Cq values for all candidate target genes were imported into qbase + version 3.0 (Biogazelle, Belgium) and analysed against the two reference genes HMBS and YWHAZ. The qbase + applies an arithmetic mean method to transform logarithmic Cq values to linear relative quantity using exponential function for relative quantification of genes and the arithmetic mean of average Cq is scaled to a given target sample [32]. The result table shows normalized relative quantities (NRQ) values that are calculated across all unknown samples per target gene. Primers used in this study were either sourced from literature or designed using NCBI Primer-BLAST tool (https:// www.ncbi.nlm.nih.gov/tools/primer-blast/) as shown in Table 2. All qPCR primers were checked for specificity using Agilent DNA 1000 Kit with the Agilent 2100 Bioanalyzer (Agilent Technologies, Inc., Waldron, Germany).

\section{Statistical analysis}

The data for each experiment was analyzed by a 2-way ANOVA using the General Linear Models (GLM) procedure of SPSS statistics version 22 (IBM Corporation) for the main effect and interactions of NE infection and 
Table 2 Sequences of primers used for quantitative real-time PCR

\begin{tabular}{|c|c|c|c|c|c|}
\hline Gene & Accession No & Sequence $\left(5^{\prime} \rightarrow 3^{\prime}\right)$ & Size, bp & Annealing $\mathrm{T},{ }^{\circ} \mathrm{C}$ & Reference \\
\hline CASP3 & NM_204725.1 & $\begin{array}{l}\text { F-TGGTGGAGGTGGAGGAGC } \\
\text { R- GTTTCTCTGTATCTTGAAGCACCA }\end{array}$ & 110 & 62 & This study \\
\hline CASP8 & NM_204592.2 & $\begin{array}{l}\text { F-GGAGCTGCTATCGGATCAAT } \\
\text { R-GGAGCTGCTCTATCGGATCAAT }\end{array}$ & 126 & 60 & This study \\
\hline $\lg A$ & S40610.1 & $\begin{array}{l}\text { F- GTCACCGTCACCTGGACACCA } \\
\text { R- ACCGATGGTCTCCTTCACATC }\end{array}$ & 192 & 64 & [33] \\
\hline $\lg G$ & X07174.1 & $\begin{array}{l}\text { F- ATCACGTCAAGGGATGCCCG } \\
\text { R- ACCAGGCACCTCAGTTTGG }\end{array}$ & 118 & 60 & [34] \\
\hline $\lg M$ & X01613.1 & $\begin{array}{l}\text { F- GCATCAGCGTCACCGAAAGC } \\
\text { R- TCCGCACTCCATCCTCTTGC }\end{array}$ & 98 & 60 & [34] \\
\hline MUC2 & XM 001234581.3 & $\begin{array}{l}\text { F- CCCTGGAAGTAGAGGTGACTG } \\
\text { R- TGACAAGCCATTGAAGGACA }\end{array}$ & 143 & 60 & [35] \\
\hline OCLD & NM_205128.1 & $\begin{array}{l}\text { F- ACGGCAGCACCTACCTCAA } \\
\text { R- GGGCGAAGAAGCAGATGAG }\end{array}$ & 123 & 60 & [36] \\
\hline TJP1 & XM_413773.4 & $\begin{array}{l}\text { F- GGATGTTATTTGGGCGGC } \\
\text { R- GTCACCGTGTGTTGTTCCCAT }\end{array}$ & 187 & 60 & [37] \\
\hline CLDN1 & NM_001013611.2 & $\begin{array}{l}\text { F- CTTCATCATTGCAGGTCTGTCAG } \\
\text { R- AAATCTGGTGTTAACGGGTGTG }\end{array}$ & 103 & 60 & [37] \\
\hline IL18 & NM_204608.1 & $\begin{array}{l}\text { F- TGTGTGTGCAGTACGGCTTAG } \\
\text { R- CTTACAAAAGGCATCGCATTC }\end{array}$ & 79 & 60 & [38] \\
\hline $11-2$ & NM_204153.1 & $\begin{array}{l}\text { F- TCTGGGACCACTGTATGCTCT } \\
\text { R- ACACCAGTGGGAAACAGTATCA }\end{array}$ & 256 & 60 & [39] \\
\hline IFN-y & Y07922 & $\begin{array}{l}\text { F- AGCTGACGGTGGTGGACCTATTATT } \\
\text { R- GGCTTTGCGCTGGATTC }\end{array}$ & 259 & 60 & {$[40]$} \\
\hline ATP1A1 & NM_205521.1 & $\begin{array}{l}\text { F- GTCAACCCGAGGGATGCTAA } \\
\text { R- ACTGCTACAATGGCACCCTG }\end{array}$ & 179 & 60 & [41] \\
\hline$B^{0} A T$ & XM_419056.5 & $\begin{array}{l}\text { F- GTGTTTGGAACCCTAAATACGAGG } \\
\text { R- TAGCATAGACCCAGCCAGGA }\end{array}$ & 72 & 60 & [41] \\
\hline GLUT2 & NM_207178.1 & $\begin{array}{l}\text { F- TGATCGTGGCACTGATGGTT } \\
\text { R- CCACCAGGAAGACGGAGATA }\end{array}$ & 171 & 60 & [41] \\
\hline SI & XM_015291762.1 & $\begin{array}{l}\text { F- GCTITAAGATGGGCAAGAGGAAG } \\
\text { R- CCACCACCAGGCAAAAGAGG }\end{array}$ & 65 & 60 & [41] \\
\hline HMBS & XM 417846.2 & $\begin{array}{l}\text { F- GGCTGGGAGAATCGCATAGG } \\
\text { R- TCCTGCAGGGCAGATACCAT }\end{array}$ & 131 & 60 & [42] \\
\hline YWHAZ & NM_001031343.1 & $\begin{array}{l}\text { F- TTGCTGCTGGAGATGACAAG } \\
\text { R- CTTCTTGATACGCCTGTTG }\end{array}$ & 61 & 60 & [43] \\
\hline
\end{tabular}

BA supplementation in experiment 1 and crude protein level and BA supplementation in experiment 2. If a significant effect was detected, differences between treatments were separated by a least significant difference test (Tukey's test). Differences between mean values were considered significant at $P \leq 0.05$.

\section{Results}

\section{Gut integrity}

As illustrated in Fig. 1a, gut integrity analysis showed higher serum FITC-d concentrations $(P<0.001)$ in birds challenged with NE compared to non-challenged birds in experiment 1. Additionally, supplementation of BA did not significantly alter gut integrity $(P>0.05)$ in this experiment. In experiment 2 , crude protein levels and
BA supplementation (Fig.1b) show no significant effect on FITC-d concentrations in chickens' serum $(P>0.05)$.

\section{Downregulation of CASP3 and CASP8 by BA supplementation}

The mRNA expression of two apoptotic genes in both experiments are shown in Fig. 2. In experiment 1, challenged birds had a significantly higher expression of caspase-3 (CASP3) $(P<0.01)$ and caspase-8 $(C A S P 8)(P<$ $0.001)$ compared to the unchallenged groups. Furthermore, BA supplementation decreased the mRNA expression of CASP3 $(P<0.001)$ and CASP8 $(P<0.05)$ in both challenged and unchallenged birds (Fig. $2 \mathrm{a}$ and $\mathrm{b})$. In experiment 2 , the addition of $\mathrm{BA}$ in diets downregulated both CASP3 $(P<0.001)$ and CASP8 $(P<0.05)$ in all birds 

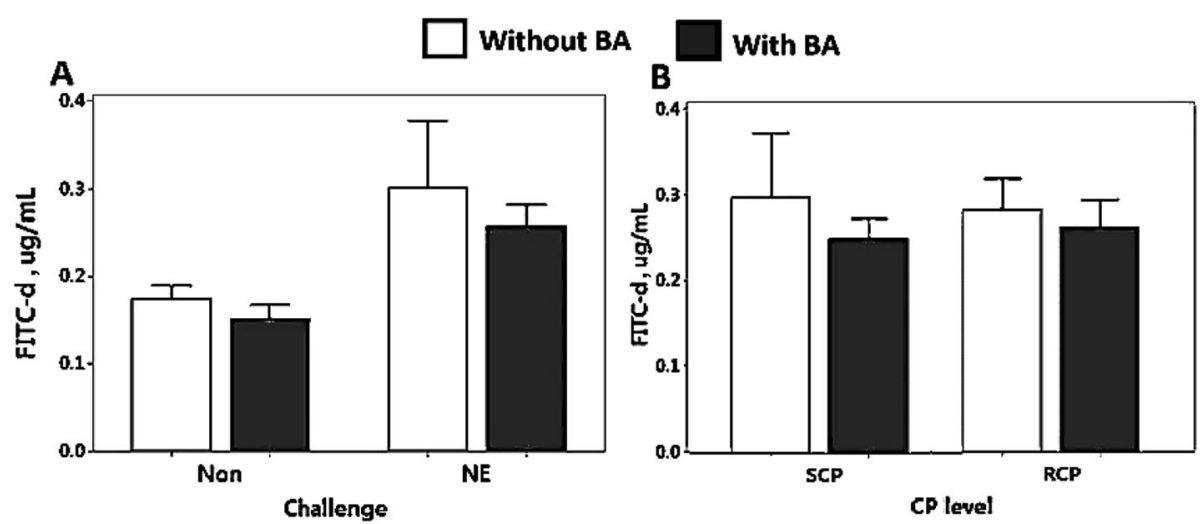

\begin{tabular}{|ll|}
\hline Challenge & $P<0.001$ \\
BA & $P=0.146$ \\
Challenge $\times B A$ & $P=0.632$ \\
\hline
\end{tabular}

\begin{tabular}{|ll|}
\hline CP level & $P=0.943$ \\
BA & $P=0.168$ \\
CP level XBA & $P=0.584$ \\
\hline
\end{tabular}

Fig. 1 Effect of Bacillus amyloliquefaciens CECT $5490\left(1.0 \times 10^{6}\right.$ CFU/g of feed) (BA) on fluorescein isothiocyanate-dextran (FITC-d) concentration in broiler serum at day 16, (a) Effect of BA supplementation and NE challenge on broiler serum FITC-d concentration; (b) Effect of crude protein levels and BA supplementation on broiler serum FITC-d concentration. CP: Crude protein. SCP: Standard protein diets, RCP: Reduced protein diets (2\% lower than standard diets). Error bars show SEM for 8 replicates for each sample test

regardless of the protein level of the diet (Fig. 2c and d). Crude protein level did not have a significant effect on the expression level of CASP3 and CASP8 $(P>0.05)$.

\section{Expression of genes encoding digestive enzymes and} nutrient transporters

Expression of genes related to nutrient transporters and digestive enzymes were evaluated in the jejunum tissue of birds in both experiments. The effect of NE challenge and BA supplementation is shown in Fig. 3a-d. The expression of GLUT2, $B^{O} A T, A T P 1 A 1$, and SI were downregulated by NE challenge $(P<0.001)$, and BA did not significantly alter the expression of these genes. Results from experiment 2 (Fig. 3e-h) showed that BA supplementation and crude protein levels did not significantly affect the expression of GLUT2, $B^{O} A T$, $A T P 1 A 1$, and SI genes $(P>0.05)$.

Upregulation of $O C L D$ and $M U C 2$ by BA supplementation The expression of tight junction proteins and $M U C 2$ in different groups is shown in Fig. 4. The expression of occludin $(O C L D)(P<0.001), T J P 1(P<0.05)$ and $M U C 2$
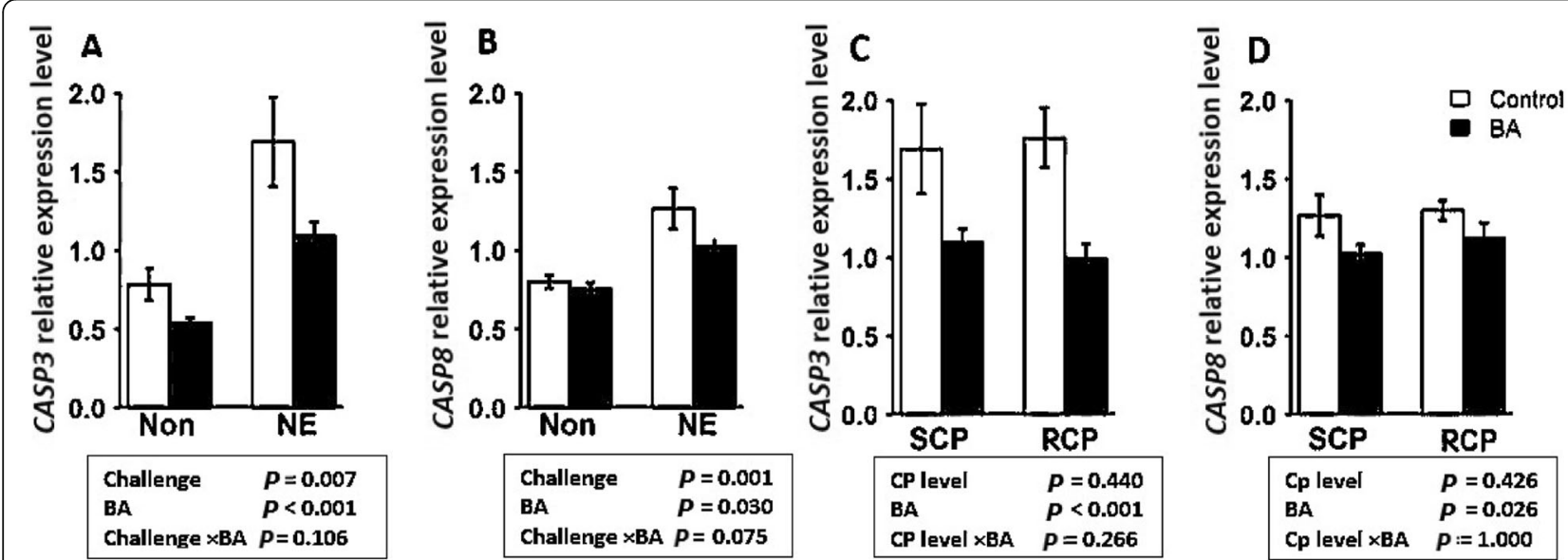

Fig. 2 Effect of Bacillus amyloliquefaciens CECT $5490\left(1.0 \times 10^{6} \mathrm{CFU} / \mathrm{g}\right.$ of feed) (BA) on two apoptosis related genes at day 16. (a-b) Effect of NE challenge and BA supplementation on caspase-3 (CASP3) and caspase-8 (CASP8) expression; (c-d) Effect of crude protein (CP) level and BA supplementation on CASP3 and CASP8 expression. Non: non-challenged; NE: NE challenged; SCP: Standard protein diet; RCP: Reduced protein diet RCP: Reduced protein diets (2\% lower than standard diets). Genes used as reference genes were HMBS and YWHAZ. Error bars show SEM for 8 replicates for each treatment 


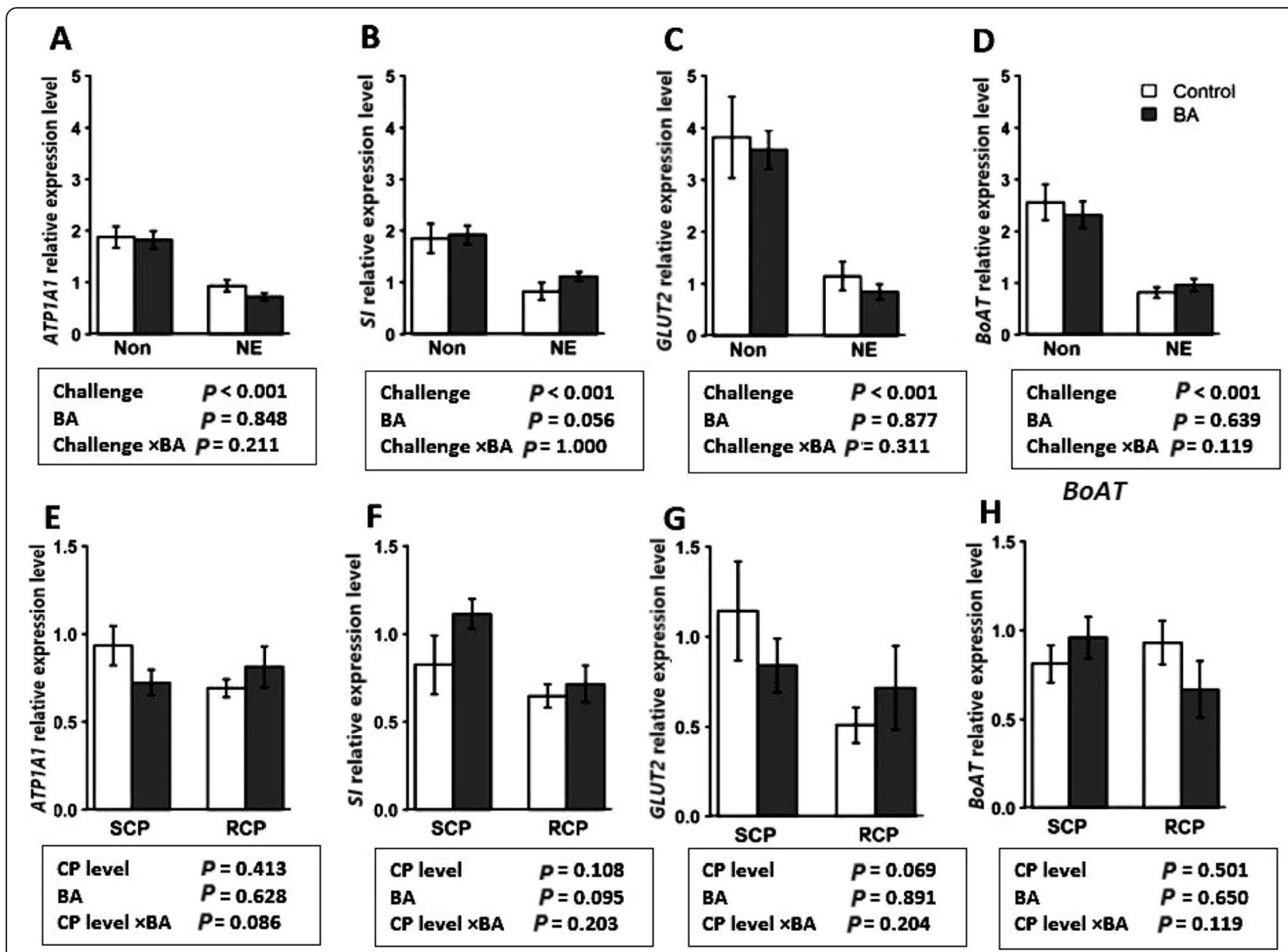

Fig. 3 Effect of Bacillus amyloliquefaciens CECT $5490\left(1.0 \times 10^{6} \mathrm{CFU} / \mathrm{g}\right.$ of feed) (BA) on genes related to enzyme and nutrient transporters at day 16. (a-d) Effect of NE challenge and BA supplementation on the expression of two enzyme (ATPase $\mathrm{Na}^{+} / \mathrm{K}^{+}$transporting subunit alpha-1 (ATP1A1) and sucrase-isomaltase $(S I)$ and nutrient transporter genes (glucose transporter-2 (GLUT2) and neutral aminoacid transporter ( $\left.B^{0} A T\right)$ (e-d) Effect of crude protein (CP) level and BA supplementation on the expression of two enzyme (ATP1A1 and SI) and nutrient transporter genes (GLUT2 and $\left.B^{O} A T\right)$. Non: non-challenged; NE: NE challenged; SCP: Standard protein diet; RCP: Reduced protein diet (2\% lower than standard diets). Genes used as reference genes were HMBS and YWHAZ. Error bars show SEM for 8 replicates for each treatment

$(P<0.001)$, were downregulated by the NE challenge (Fig. 4a-c). The supplementation of BA significantly increased the expression level of OCLD $(P<0.05)$ regardless of the challenged. In experiment 2, BA supplementation increased OCLD expression $(P<0.05)$, TJP1 $(P<0.05)$ and MUC2 $(P<0.001)$ regardless of the crude protein level in diets (Fig. $4 \mathrm{~d}-\mathrm{f}$ ). The expression of $C L D N 1$ was not affected in either of the experiments $(P>0.05)$.

Upregulation of $\lg A$, $\lg M$, and downregulation of $I N F-\gamma$ by BA supplementation

Figure 5 illustrates the mRNA expression of six immunity-related genes affected by NE challenge and BA supplementation. As shown in Fig. 5a, an NE challenge $\times$ BA interaction was observed for interferon- $\gamma$ $(I F N-\gamma)$ where BA supplementation downregulated IFN$\gamma$ expression only in the NE challenged birds $(P<0.001)$.
An NE challenge $\times$ BA interaction was observed for $\operatorname{IgG}$ $(P<0.01)$ and $\operatorname{IgM}(P<0.05)$, where the NE challenge with no BA supplementation shows the lowest values, however, the supplementation of BA give similar results as the unchallenged birds with or without BA supplementation. The effect of crude protein level and BA is illustrated in Fig. 6. Birds fed with BA showed downregulation in the expression of $I N F-\gamma$ $(P<0.01)$ and upregulation of $\operatorname{IgA}(P<0.05), \operatorname{IgG}(P<0.01)$, and $\operatorname{IgM}(P<0.05)$, regardless of $C P$ level in the diet. No difference was observed for the expression of IL18 $(P>0.05)$ in response to the $\mathrm{BA}$ supplementation and $\mathrm{CP}$ level in diet as main effects or interactively.

\section{Discussion}

This study investigated the expression of a series of genes encoding proteins related to immunity, intestinal integrity, apoptosis and mucin production in broiler jejunum tissue in response to the supplementation of BA- 


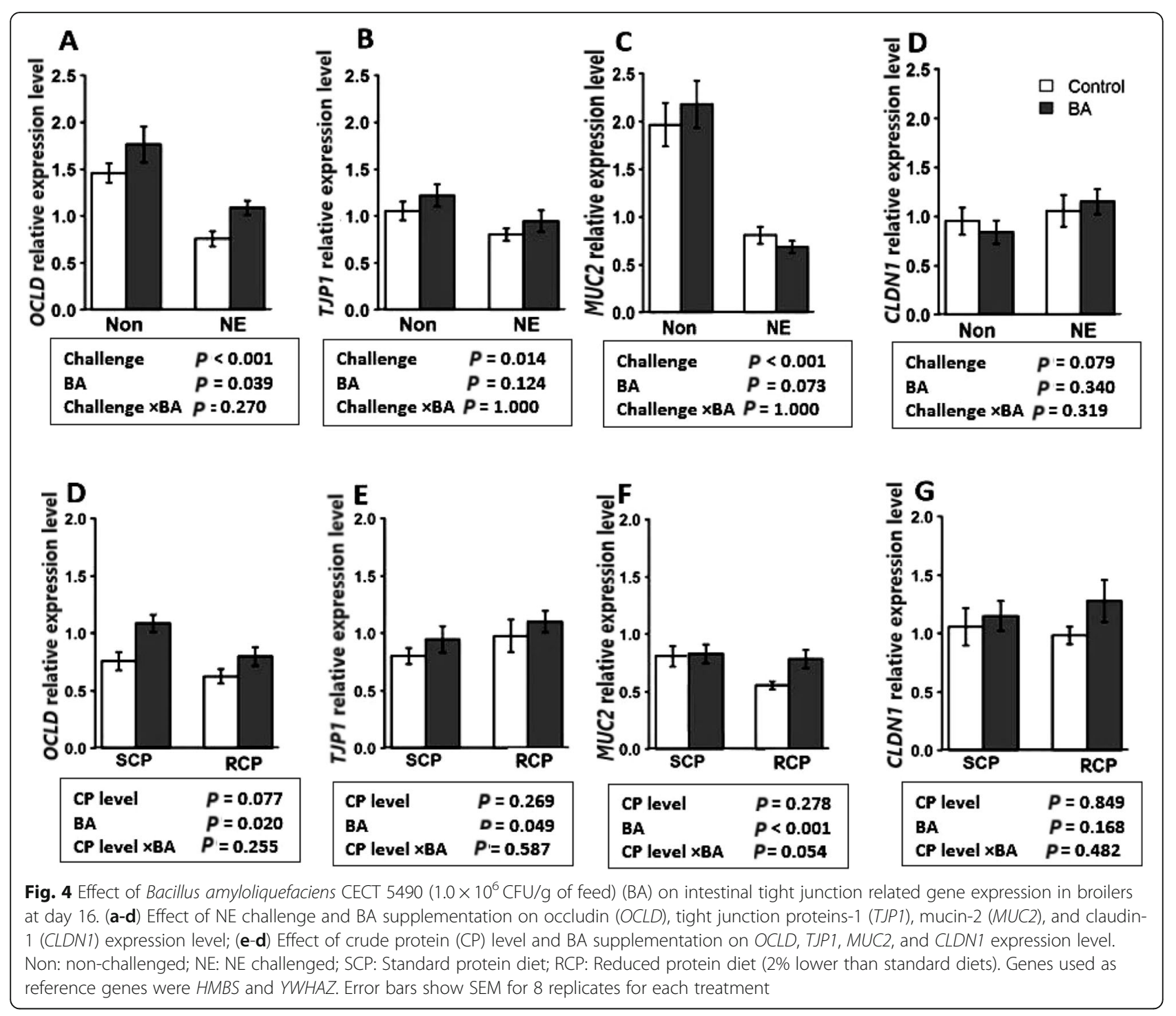

5460 when fed diet with different levels of $\mathrm{CP}$ and/or challenged with NE. The BA supplementation reduced the apoptosis gene expression and had a positive effect on the immunity and mucosal gene expression in the intestine. The present data lead to the acceptance of our hypothesis that BA, as a probiotic, can improve gut health of broiler chickens likely through the modulation of intestinal genes responsible for a variety of functions in the intestine.

We have previously reported that successful subclinical NE challenge was applied in this experiment, as performance traits were significantly affected by the challenge [28]. The NE challenge significantly impaired BWG and FCR in birds, and increased lesion scores in these groups [28]. Most of the genes evaluated in this experiment were affected by the NE challenge. The higher expression of caspase and lower expression of immunoglobulin and interleukin proteins prove the altered cell death and impaired immunity system in the challenged birds that further confirm the occurrence of the NE disease in the study.

The small intestine has a primitive function in the digestion and nutrient absorption processes. The structure and function of the intestinal mucosa, which in part is associated with the morphological characteristics, highly depends on the balance between proliferation and apoptosis [44]. In the present study, lower expression of $M U C 2$ in the NE challenged groups can be related to the inflammation in the gut. Inflammatory lesions can reduce goblet cells, which produce mucin and contain the $M U C 2$ gene, prevent the mucosal layer from replenishing and increase the chance for further infection, bacterial translocation and inflammation in the intestine $[38,45]$. In this experiment, the expression of $M U C 2$ in the birds fed with BA was higher compared to the nonsupplemented groups indicating positive effects of this 


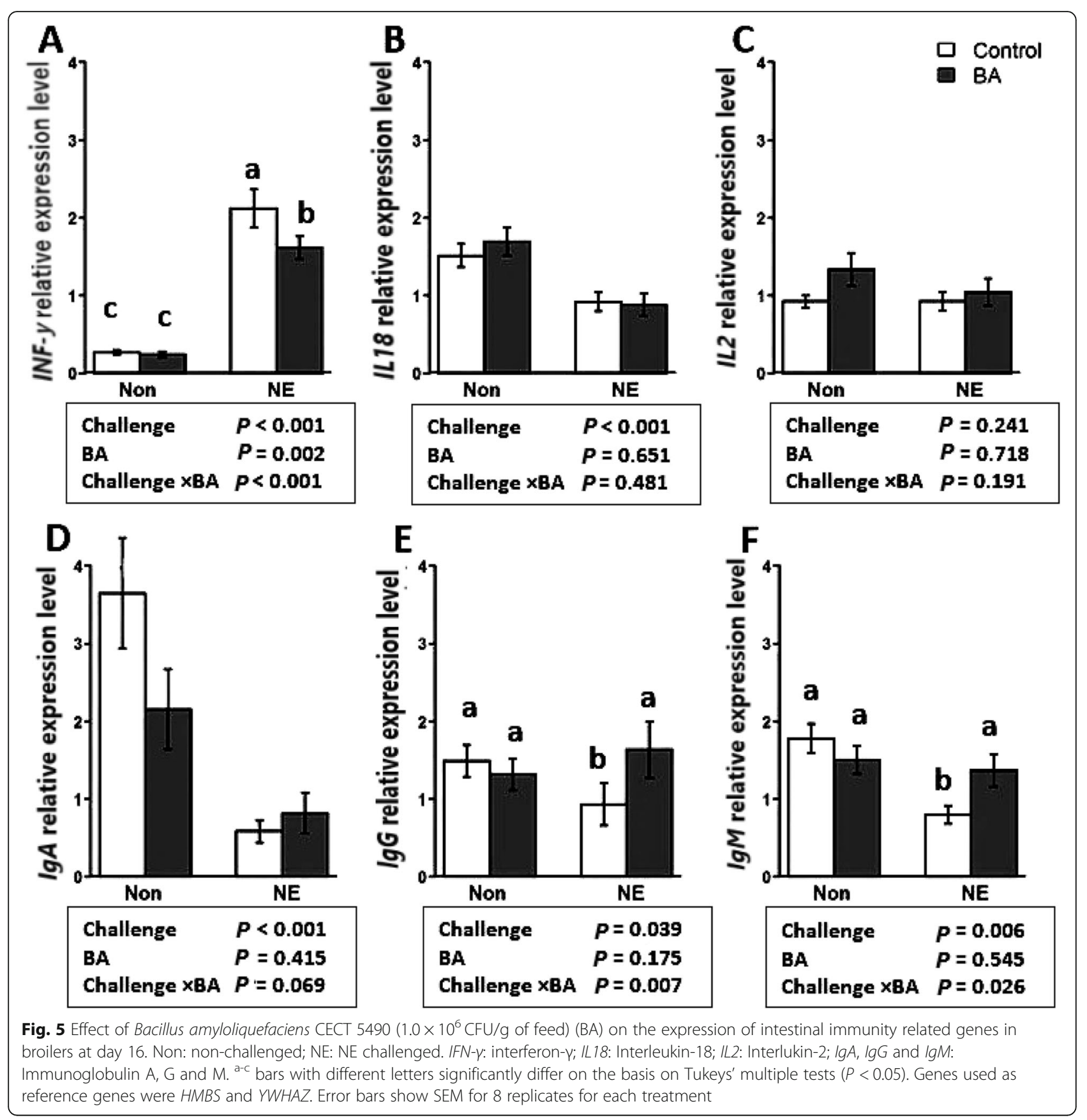

probiotic on the protection of the birds from disease. Previous studies have similarly reported the positive effects of Bacillus-based probiotics on the MUC2 mRNA expression in chicken jejunum [46, 47].

Activation of pro-inflammatory cytokines such as IFN$\gamma$ and/or tumor necrosis factor- $\alpha$ (TNF- $\alpha$ ) can promote cell death by apoptosis and also lead to $\beta$-cell destruction [48]. Our results demonstrate that the addition of BA has downregulated expression of both proinflammatory cytokines $(I F N-\gamma)$ and apoptosis genes (CASP3 and CASP8) in NE challenged birds. Caspases are pre-apoptotic proteins, expressed in most of the cells that are active in the cell death pathways. The C. perfringens enterotoxin (CPE) can bind to enterocytes then oligomerize into a hexametric prepore on the cell membrane surface and form an active pore, which can then cause an increased influx of $\mathrm{Ca}^{2+}$ that may lead to enterocyte cell death [49]. The CASP3 and CASP8 proteins are executioner caspases which can be used as markers for cell apoptosis [50]. The results from the current study revealed that the supplementation of BA reduced the relative expression of both CASP3 and CASP8 in the 


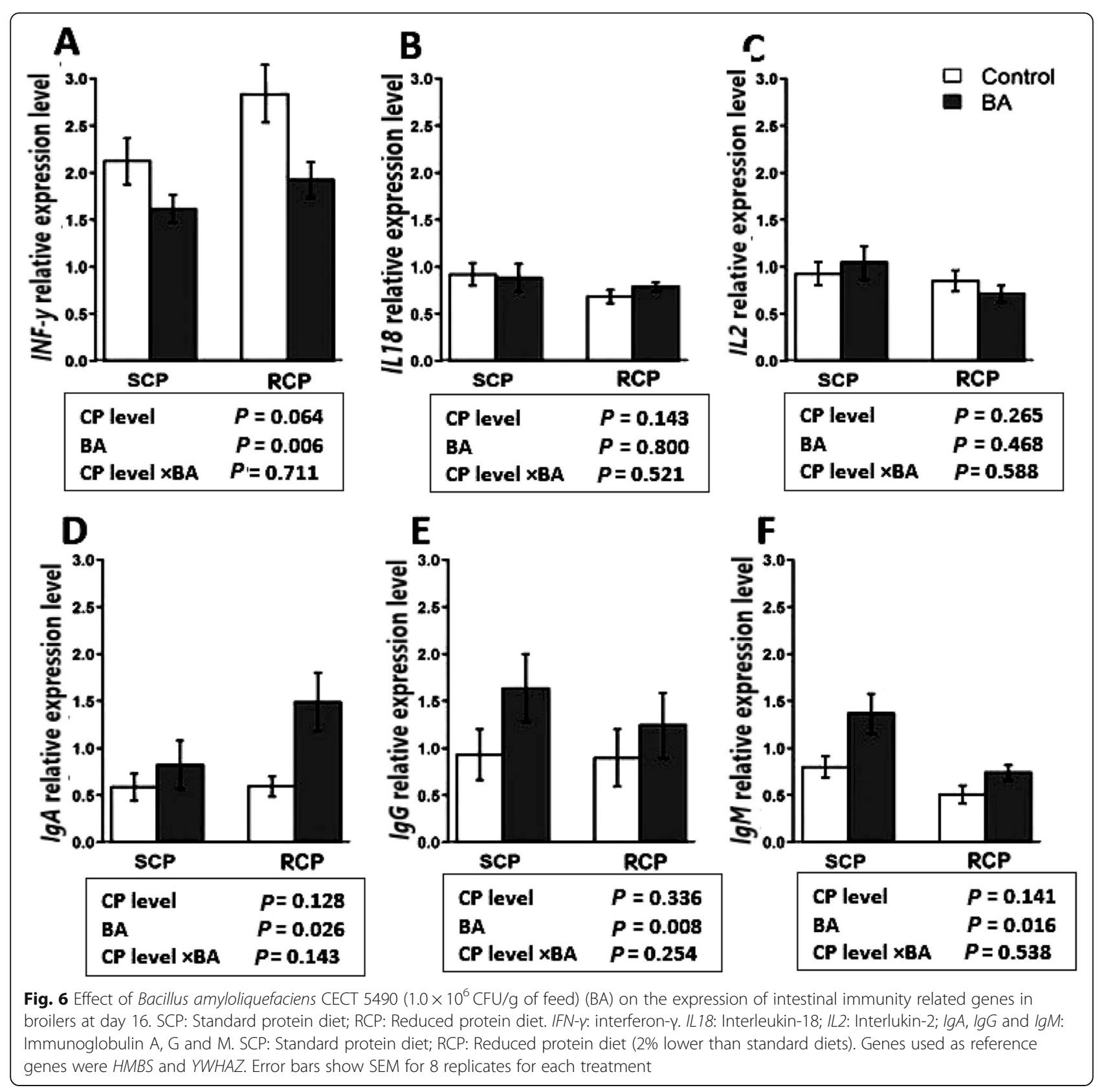

challenged birds, as has also been shown with Bacillus spp. previously [51]. The BA supplementation has shown to reduce CASP3 activity and reduce the activation of other apoptosis pathways related to oxidative stress in porcine epithelium cell line $[52,53]$. Lower activity of cell death pathways implies a lower inflammatory pathway activity, which may lead to improved health of the intestine.

The intestinal epithelium is in permanent contact with dynamic enteric flora. The intestinal barrier and tight junctions are major defense mechanisms used to maintain epithelial integrity for protecting the organism from the environment. In the present study, a higher level of
FITC-d concentrations in the bloodstream and lower mRNA expression of tight junction genes such as OCLD and TJP1 in the NE infected birds indicate the damage in the paracellular permeability, which has been observed in previous studies $[54,55]$. The addition of BA upregulated the expression of OCLD in challenged birds. The expression level of this protein is known to correlate with the number of tight junction strands in the epithelia [56]. Tight junctions regulate nutrient absorption, homeostasis, and defense against invading pathogens in the intestine and are known to be the main indicators for intestinal epithelium health. Bacillus subtilis as a supplemented probiotic in mice with inflammatory 
bowel disease has shown to upregulate expression of tight junction genes, including $O C L D$, and thus improve the barrier function [57]. A mixture of B. subtilis and Saccharomyces boulardii as probiotics have shown to increase the expression of tight junction genes such as OCLD, claudin-2 (CLDN2), and claudin-2 (CLDN3) in broilers [58].

Furthermore, a link between increased levels of proinflammatory cytokines and intestinal permeability has been reported [59]. Secretion of inflammatory cytokines that are immunoregulatory peptides can alter tight junction gene expression [60]. Interferon- $\gamma$ elaborates regulation of inflammatory immune responses, and $C$. perfringens infection has shown to increase the expression of this gene $[55,61]$. This protein can rearrange and redistribute the actin cytoskeleton in the intestine and increase paracellular permeability [62]. It can also regulate intestinal epithelial cell proliferation and apoptosis through AKT- $\beta$-catenin pathways [63]. Bacillusbased probiotics have shown to promote the synthesis of endogenous antimicrobial peptides in the gut, thus enhance the innate immune function [64]. Studies have shown that these probiotics can reduce the mRNA expression of IFN- $\gamma$, which may be attributed to decreased pathogen load in the gut [61]. The improvement in tight junction protein expressions mostly observed in experiment 2 could be related to the downregulated expression of IFN- $\gamma$ triggered by BA. The BA supplementation can alleviate lipopolysaccharide-induced intestinal damage in chicken [65] and reduce mRNA levels of proinflammatory cytokines such as tumor necrosis factor in mice [66]. The suppression of inflammatory cytokines by the supplementation of BA may have led to the improved intestinal gut integrity.

The mucosal plasma cells in the lamina propria, produce secretory immunoglobulins such as IgA, and IgM that act as the first line of defense in the small intestine and other luminal surfaces [67]. All NE challenged birds fed with BA supplemented diets showed higher expression of immunoglobulins in the intestine. One reason for the lower expression of $\operatorname{IgA}$ and $\operatorname{Ig} M$ observed in the challenged birds of this study, could be due to the damaged intestinal structure, along with the downregulation of the genes involved in the amino acid uptake in the intestinal tissue [68-70]. Immunoglobulin proteins such as IgA, IgM, and IgG, are present in the enterocyte brush border and are delivered to the mucus layer [16]. Similar to the current results, Wang et al. [71] reported a decrease of IgA+ B cells in NE infected chickens. Bacillusbased probiotics have shown to increase the availability of some amino acids [25] and to increase digestive enzyme activity, protein efficiency, and nutrient retention in broilers [72]. There is a direct correlation between amino acid balance on mucin production [73], thus the improved amino acid uptake could have led to increased expression of $M U C 2$ observed in the current results. We have previously observed the positive effects of BA supplementation on amino acid digestibility [28]. It should be noted that the number of genes evaluated in this study are extremely limited. There are immense numbers of nutrient transporter, and enzyme proteins that may have been affected by BA. Further study is needed to clearly understand the effects of BA supplementation on gut health and nutrient uptake.

\section{Conclusion}

Taken together, the results of this study suggest that the dietary supplementation of BA could alleviate the undesirable effects of NE of intestinal cell death and immune responses, hence further improve performance. Further investigation on the effects of this Bacillus strain is needed for a better understanding of the mechanisms underlying possible positive effects of the probiotic supplementation to the birds under challenge and unchallenged conditions.

\section{Abbreviations}

NE: Necrotic enteritis; BA: Bacillus amyloliquefaciens CECT 5940; SCP: Standard protein diets; RCP: Reduced protein diets; FITC-d: Fluorescein isothiocyanatedextran; CASP3: Caspase-3; CASP8: Caspase-8; CLDN1: Claudin 1;

OCLD: Occludin; MUC2: Mucin 2; IgA: Immunoglobulin-A;

IgM: Immunoglobulin-M; IgG: Immunoglobulin-G; TJP1: Tight junction

protein-1; GLUT2: Glucose transporter-2; ATP1A1: ATPase $\mathrm{Na}^{+} / \mathrm{K}^{+}$Transporting subunit alpha-1; SI: Sucrase-isomerase; B AT: Neutral amino acid transporter;

IL18: Interleukin-18; IL-2: Interleukin-2; IFN- $\gamma$ : Interferon- $\gamma$

\section{Acknowledgments}

The authors thank Ms. Petrina Young of Eimeria Pty Ltd. for providing Eimeria species. Prof. Robert Moore for providing Clostridium perfringens EHE-NE18.

Mrs. Shuyu Song and Mr. Jonathan Clay for their help and guidance with the lab work.

\section{Authors' contributions}

KGN performed animal trial, laboratory experiments, and statistical analysis, designed the study and drafted the manuscript; JD and KD assisted in study design, feed formulation, data evaluation and reviewed manuscript; SK assisted in laboratory work, collection and analysis of data; RS and MC contributed to study design and reviewed the manuscript; and SBW coordinated and designed the study, contributed to data collection and statistical analyses, and critically reviewed the manuscript. The authors read and approved the final manuscript.

\section{Funding \\ This research was supported by grants of Evonik Nutrition \& Care GmbH, Germany.}

Availability of data and materials

Data may be provided following request to the corresponding author.

Ethics approval and consent to participate

All procedures of this study were reviewed and approved by the Animal Ethics Committee of the University of New England (17/127).

Consent for publication

Not applicable.

Competing interests

The authors declare that they have no competing interests. 


\section{Author details}

${ }^{1}$ School of Environmental and Rural Science, University of New England, Armidale, NSW 2351, Australia. 'Evonik Nutrition \& Care GmbH, 10-B226, Rodenbacher Chaussee 4, 63457 Hanau-Wolfgang, Germany. ${ }^{3}$ University of New England, Armidale, NSW 2351, Australia.

Received: 26 March 2020 Accepted: 26 August 2020

Published online: 16 October 2020

\section{References}

1. Shojadoost B, Vince AR, Prescott JF. The successful experimental induction of necrotic enteritis in chickens by Clostridium perfringens: a critical review. Vet Res. 2012;43(74):1-12.

2. Wade B, Keyburn A. The true cost of necrotic enteritis. World Poult. 2015; 31(7):16-7.

3. Castanon Jl. History of the use of antibiotic as growth promoters in European poultry feeds. Poult Sci. 2007;86(11):2466-71.

4. Chowdhury R, Islam K, Khan M, Karim M, Haque M, Khatun M, et al. Effect of citric acid, avilamycin, and their combination on the performance, tibia ash, and immune status of broilers. Poult Sci. 2009:88(8):1616-22.

5. Xu S, Lin Y, Zeng D, Zhou M, Zeng $Y$, Wang $H$, et al. Bacillus licheniformis normalize the ileum microbiota of chickens infected with necrotic enteritis. Sci Rep. 2018;8(1):1744

6. Lee JY, Shim JM, Yao Z, Liu X, Lee KW, Kim HJ, et al. Antimicrobial activity of Bacillus amyloliquefaciens EMD17 isolated from Cheonggukjang and potential use as a starter for fermented soy foods. Food Sci Biotechnol. 2016;25(2):525-32

7. Chakraborty K, Thilakan B, Raola VK. Previously undescribed antibacterial polyketides from heterotrophic Bacillus amyloliquefaciens associated with seaweed Padina gymnospora. Appl Biochem Biotechnol. 2018;184(2):71632.

8. Lee Y-J, Kim B-K, Lee B-H, Jo K-I, Lee N-K, Chung C-H, et al. Purification and characterization of cellulase produced by Bacillus amyoliquefaciens DL-3 utilizing rice hull. Bioresour Technol. 2008;99(2):378-86.

9. Bindiya E, Tina K, Sasidharan RS, Bhat SG. BaCf3: highly thermostable bacteriocin from Bacillus amyloliquefaciens BTSS3 antagonistic on foodborne pathogens. 3. Biotech. 2019;9(4):1-7.

10. Ulyanova $V$, Vershinina $V$, llinskaya $O$. Barnase and binase: twins with distinct fates. FEBS J. 2011;278(19):3633-43.

11. de Oliveira MJK, Sakomura NK, de Paula Dorigam JC, Doranalli K, Soares L, Viana GS. Bacillus amyloliquefaciens CECT 5940 alone or in combination with antibiotic growth promoters improves performance in broilers under enteric pathogen challenge. In: Poult. Sci. A. 2nd Latin American scientific conference; 2018. p. 112

12. Alina SO, Constantinscu F, Petruța CC. Biodiversity of Bacillus subtilis group and beneficial traits of Bacillus species useful in plant protection. Rom Biotechno Lett. 2015;20(5):10737-50.

13. Lan $Y$, Verstegen $M$, Tamminga S, Williams B. The role of the commensal gut microbial community in broiler chickens. Worlds Poult Sci J. 2005;61(1): 95-104.

14. Elphick D, Mahida Y. Paneth cells: their role in innate immunity and inflammatory disease. Gut. 2005;54(12):1802-9.

15. Sovran B, Lu P, Loonen LM, Hugenholtz F, Belzer C, Stolte EH, et al. Identification of commensal species positively correlated with early stress responses to a compromised mucus barrier. Inflamm Bowel Dis. 2016;22(4): 826-40.

16. Hansen GH, Pedersen ED, Immerdal L, Niels-Christiansen LL, Danielsen EM. Anti-glycosyl antibodies in lipid rafts of the enterocyte brush border: a possible host defense against pathogens. Am J Physiol Gastrointest Liver Physiol. 2005;289(6):1100-7.

17. Norbury CJ, Hickson ID. Cellular responses to DNA damage. Annu Rev Pharmacol Toxicol. 2001;41(1):367-401.

18. Cohen GM. Caspases: the executioners of apoptosis. Biochem J. 1997;326(1): $1-16$.

19. Fotiadis D, Kanai Y, Palacín M. The SLC3 and SLC7 families of amino acid transporters. Mol Aspects Med. 2013;34(3):139-58.

20. Uldry M, Ibberson M, Hosokawa M, Thorens B. GLUT2 is a high affinity glucosamine transporter. FEBS Lett. 2002;524(3):199-203.

21. Hediger MA, Romero MF, Peng JB, Rolfs A, Takanaga $H$, Bruford EA. The $A B C s$ of solute carriers: physiological, pathological and therapeutic implications of human membrane transport proteins. Pflugers Arch. 2004; 447(5):465-8.

22. Gómez S, Angeles M, Mojica M, Jalukar S. Combination of an enzymatically hydrolyzed yeast and yeast culture with a direct-fed microbial in the feeds of broiler chickens. Asian-Australas J Anim Sci. 2012;25(5):665.

23. Cooper KK, Songer JG. Virulence of Clostridium perfringens in an experimental model of poultry necrotic enteritis. Vet Microbiol. 2010;142: 323-8.

24. Katoch S, Dev S, Rajput R. Effect of probiotic supplementation in broiler birds offered feed formulated with lower protein densities. Int J Livest Res. 2017:5(36):90-101.

25. Suartika IG, Sumadi I, Bidura I. Effect of probiotic supplementation on low protein diet on broiler performance. E-J Anim Sci Uday Uni. 2014;3(2):1-10.

26. Van Harn J, Dijkslag M, Van Krimpen M. Effect of low protein diets supplemented with free amino acids on growth performance, slaughter yield, litter quality, and footpad lesions of male broilers. Poult Sci. 2019; 98(10):4868-77.

27. Shao D, Shen Y, Zhao X, Wang Q, Hu Y, Shi S, et al. Low-protein diets with balanced amino acids reduce nitrogen excretion and foot pad dermatitis without affecting the growth performance and meat quality of free-range yellow broilers. Ital J Anim Sci. 2018;17(3):698-705.

28. Gharib-Naseri K, Kheravii SK, Dorigam JCP, Doranalli K, Morgan N, Swick R, et al. Bacillus amyloliquefaciens CECT 5940 improves performance and gut function in broilers fed different levels of protein and/or under necrotic enteritis challenge. Anim Nutr. 2020. https://doi.org/10.1016/j.aninu.2020.05. 004.

29. Aviagen. Ross broiler management manual. http://pt.aviagen.com/assets/ TechCenter/RossBroiler/RossBroilerManual. 2011. p. 10-35.

30. Rodgers NJ, Swick RA, Geier MS, Moore RJ, Choct M, Wu S-B. A multifactorial analysis of the extent to which Eimeria and fishmeal predispose broiler chickens to necrotic enteritis. Avian Dis. 2015;59(1):38-45

31. Vicuna EA, Kuttappan VA, Galarza-Seeber R, Latorre JD, Faulkner OB, Hargis $B M$, et al. Effect of dexamethasone in feed on intestinal permeability, differential white blood cell counts, and immune organs in broiler chicks. Poult Sci. 2015;94(9):2075-80.

32. Vandesompele J, De Preter K, Pattyn F, Poppe B, Van Roy N, De Paepe A, et al. Accurate normalization of real-time quantitative RT-PCR data by geometric averaging of multiple internal control genes. Genome Biol. 2002; 3(7):research0034.1.

33. Lammers A, Wieland WH, Kruijt L, Jansma A, Straetemans T, Schots A, et al, Successive immunoglobulin and cytokine expression in the small intestine of juvenile chicken. Dev Comp Immunol. 2010;34(12):1254-62.

34. Zhao FQ, Zhang ZW, Yao HD, Wang LL, Liu T, Yu XY, et al. Effects of cold stress on mRNA expression of immunoglobulin and cytokine in the small intestine of broilers. Res Vet Sci. 2013;95(1):146-55.

35. Fan X, Liu S, Liu G, Zhao J, Jiao H, Wang X, et al. Vitamin a deficiency impairs mucin expression and suppresses the mucosal immune function of the respiratory tract in chicks. PLoS One. 2015;10(9):1-16.

36. Du E, Wang W, Gan L, Li Z, Guo S, Guo Y. Effects of thymol and carvacrol supplementation on intestinal integrity and immune responses of broiler chickens challenged with Clostridium perfringens. J Anim Sci Biotechnol. 2016;7(19):1-10.

37. Zanu H, Keerqin C, Kheravii S, Morgan N, Wu S-B, Bedford M, et al. Influence of meat and bone meal, phytase, and antibiotics on broiler chickens challenged with subclinical necrotic enteritis: 2. Intestinal permeability, organ weights, hematology, intestinal morphology, and jejunal gene expression. Poult Sci. 2020;99(5):2581-94.

38. Forder RE, Nattrass GS, Geier MS, Hughes RJ, Hynd PI. Quantitative analyses of genes associated with mucin synthesis of broiler chickens with induced necrotic enteritis. Poult Sci. 2012;91(6):1335-41.

39. Liu J, Liu L, Li L, Tian D, Li W, Xu L, et al. Protective immunity induced by Eimeria common antigen 14-3-3 against Eimeria tenella, Eimeria acervulina and Eimeria maxima. BMC Vet Res. 2018;14(1):337.

40. Li Z, Wang W, Liu D, Guo Y. Effects of Lactobacillus acidophilus on the growth performance and intestinal health of broilers challenged with Clostridium perfringens. J Anim Sci Biotechnol. 2018;9(1):25-35.

41. Kheravii SK, Swick RA, Choct M, Wu S-B. Upregulation of genes encoding digestive enzymes and nutrient transporters in the digestive system of broiler chickens by dietary supplementation of fiber and inclusion of coarse particle size corn. BMC Genomics. 2018;19(1):208-22.

42. Yin R, Liu X, Liu C, Ding Z, Zhang X, Tian F, et al. Systematic selection of housekeeping genes for gene expression normalization in chicken embryo 
fibroblasts infected with Newcastle disease virus. Biochem Biophys Res Commun. 2011:413(4):537-40.

43. Bagés S, Estany J, Tor M, Pena R. Investigating reference genes for quantitative real-time PCR analysis across four chicken tissues. Gene. 2015; 561(1):82-7.

44. Murakami A, Sakamoto M, Natali M, Souza L, Franco J. Supplementation of glutamine and vitamin $\mathrm{E}$ on the morphometry of the intestinal mucosa in broiler chickens. Poult Sci. 2007;86(3):488-95.

45. Wei X, Yang Z, Rey FE, Ridaura VK, Davidson NO, Gordon JI, et al. Fatty acid synthase modulates intestinal barrier function through palmitoylation of mucin 2. Cell Host Microbe. 2012;11(2):140-52.

46. Aliakbarpour HR, Chamani M, Rahimi G, Sadeghi AA, Qujeq D. The Bacillus subtilis and lactic acid bacteria probiotics influences intestinal mucin gene expression, Histomorphology and growth performance in broilers. AsianAustralas J Anim Sci. 2012;25(9):1285-93.

47. Gadde UD, Oh S, Lee Y, Davis E, Zimmerman N, Rehberger T, et al. Dietary Bacillus subtilis-based direct-fed microbials alleviate LPS-induced intestinal immunological stress and improve intestinal barrier gene expression in commercial broiler chickens. Res Vet Sci. 2017;114:236-43.

48. Cnop M, Welsh N, Jonas JC, Jörns A, Lenzen S, Eizirik DL. Mechanisms of pancreatic $\beta$-cell death in type 1 and type 2 diabetes: many differences, few similarities. Diabetes. 2005;54(suppl 2):S97-S107.

49. Chen J, Theoret JR, Shrestha A, Smedley JG, McClane BA. Cysteine-scanning mutagenesis supports the importance of Clostridium perfringens enterotoxin amino acids 80 to 106 for membrane insertion and pore formation. Infect Immun. 2012;80(12):4078-88

50. Bowen JM, Gibson RJ, Cummins AG, Keefe DM. Intestinal mucositis: the role of the $\mathrm{BCl}-2$ family, $\mathrm{p} 53$ and caspases in chemotherapy-induced damage. Support Care Cancer. 2006;14(7):713-31.

51. Wu T, Zhang Y, Lv Y, Li P, Yi D, Wang L, et al. Beneficial impact and molecular mechanism of Bacillus coagulans on piglets' intestine. Int J Mol Sci. 2018;19(7):2084-101.

52. Wu Y, Xu H, Cao X, Liu R, Tang L, Zeng Z, et al. Bacillus amyloliquefaciens ameliorates $\mathrm{H} 2 \mathrm{O}$ 2-induced oxidative damage by regulating transporters, tight junctions, and apoptosis gene expression in cell line IPEC-1. Probiotics Antimicro. 2019;1:1-8.

53. Wang Y, Wu Y, Wang Y, Fu A, Gong L, Li W, et al. Bacillus amyloliquefaciens SC06 alleviates the oxidative stress of IPEC-1 via modulating Nrf2/Keap1 signaling pathway and decreasing ROS production. Appl Microbiol Biotechnol. 2017:101(7):3015-26.

54. Latorre JD, Adhikari B, Park SH, Teague KD, Graham LE, Mahaffey BD, et al. Evaluation of the epithelial barrier function and ileal microbiome in an established necrotic enteritis challenge model in broiler chickens. Front Vet Sci. 2018:5(199):1-11.

55. Park SS, Lillehoj HS, Allen PC, Park DW, FitzCoy S, Bautista DA, et al. Immunopathology and cytokine responses in broiler chickens coinfected with Eimeria maxima and Clostridium perfringens with the use of an animal model of necrotic enteritis. Avian Dis. 2008;52(1):14-22.

56. Medina R, Rahner C, Mitic L, Anderson J, Van Itallie C. Occludin localization at the tight junction requires the second extracellular loop. J Membr Biol. 2000;178(3):235-47.

57. Gong Y, Li H, Li Y. Effects of Bacillus subtilis on epithelial tight junctions of mice with inflammatory bowel disease. J Interferon Cytokine Res. 2016;36(2): 75-85.

58. Rajput IR, Li LY, Xin X, Wu BB, Juan ZL, Cui ZW, et al. Effect of Saccharomyces boulardii and Bacillus subtilis B10 on intestinal ultrastructure modulation and mucosal immunity development mechanism in broiler chickens. Poult Sci. 2013;92(4):956-65.

59. Al-Sadi R, Guo S, Ye D, Ma TY. TNF-a modulation of intestinal epithelial tight junction barrier is regulated by ERK1/2 activation of Elk-1. Am J Pathol. 2013; 183(6):1871-84.

60. Sakaguchi T, Gu X, Golden HM, Suh E, Rhoads DB, Reinecker H-C. Cloning of the human claudin-2 $5^{\prime}$-flanking region revealed a TATA-less promoter with conserved binding sites in mouse and human for caudal-related homeodomain proteins and hepatocyte nuclear factor-1a. J Biol Chem. 2002;277(24):21361-70

61. Wu Y, Shao Y, Song B, Zhen W, Wang Z, Guo Y, et al. Effects of Bacillus coagulans supplementation on the growth performance and gut health of broiler chickens with Clostridium perfringens-induced necrotic enteritis. Rev Bras Cienc Avic. 2018:9(9):1-14.
62. Bruewer M, Utech M, Ivanov Al, Hopkins AM, Parkos CA, Nusrat A. Interferon- $y$ induces internalization of epithelial tight junction proteins via a macropinocytosis-like process. FASEB J. 2005;19(8):923-33.

63. Nava P, Koch S, Laukoetter MG, Lee WY, Kolegraff K, Capaldo CT, et al. Interferon- $\gamma$ regulates intestinal epithelial homeostasis through converging B-catenin signaling pathways. Immunity. 2010;32(3):392-402.

64. Hong HA, Duc LH, Cutting SM. The use of bacterial spore formers as probiotics. FEMS Microbiology Rev. 2005;29(4):813-35.

65. Li Y, Zhang H, Chen YP, Yang MX, Zhang LL, Lu ZX, et al. Bacillus amyloliquefaciens supplementation alleviates immunological stress in lipopolysaccharide-challenged broilers at early age. Poult Sci. 2015;94(7): 1504-11.

66. Islam VH, Babu NP, Pandikumar P, Ignacimuthu S. Isolation and characterization of putative probiotic bacterial strain, Bacillus amyloliquefaciens, from north east Himalayan soil based on in vitro and in vivo functional properties. Probiotics Antimicro. 2011;3(4):175-85.

67. Brandtzaeg P, Johansen FE. Mucosal B cells: phenotypic characteristics, transcriptional regulation, and homing properties. Immunol Rev. 2005; 206(1):32-63.

68. Konashi S, Takahashi K, Akiba Y. Effects of dietary essential amino acid deficiencies on immunological variables in broiler chickens. Br J Nutr. 2000; 83(4):449-56.

69. Jones E. Immunoglobulins and the gut. Gut. 1972;13(10):825-35.

70. Zhang Q, Chen X, Eicher S, Ajuwon K, Applegate T. Effect of threonine on secretory immune system using a chicken intestinal ex vivo model with lipopolysaccharide challenge. Poult Sci. 2017;96(9):3043-51.

71. Wang H, Ni X, Qing X, Liu L, Lai J, Khalique A, et al. Probiotic enhanced intestinal immunity in broilers against subclinical necrotic enteritis. Front Immunol. 2017;8(1592):1-14.

72. Murugesan GR, Gabler NK, Persia ME. Effects of direct-fed microbial supplementation on broiler performance, intestinal nutrient transport and integrity under experimental conditions with increased microbial challenge. Br Poultry Sci. 2014;55(1):89-97.

73. Lien $\mathrm{K}$, Sauer $\mathrm{W}$, He J. Dietary influences on the secretion into and degradation of mucin in the digestive tract of monogastric animals and humans. J Anim Feed Sci. 2001;10(2):223-46.

Ready to submit your research? Choose BMC and benefit from

- fast, convenient online submission

- thorough peer review by experienced researchers in your field

- rapid publication on acceptance

- support for research data, including large and complex data types

- gold Open Access which fosters wider collaboration and increased citations

- maximum visibility for your research: over $100 \mathrm{M}$ website views per year

At $\mathrm{BMC}$, research is always in progress.

Learn more biomedcentral.com/submissions 